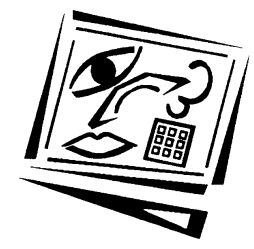

\title{
An investigation of student teachers' attitudes to the use of media triggered problem based learning
}

\author{
Angela Kit Fong Ma \\ The Hong Kong Institute of Education \\ John O'Toole \\ The University of Newcastle \\ Michael Keppell \\ Charles Sturt University
}

\begin{abstract}
This study investigates how teacher education students responded to a particular suite of educational products that involved media based educational learning objects, and their attitudes to them in fostering student centred learning in general, and problem based learning in particular, with the ultimate goal of enhancing and improving the quality of teacher training. Two lines of inquiry have been followed throughout the investigation:

i. to identify and describe student attitudes to the newly developed video rich PBL courseware for teacher education; and

ii. to explore how such educational courseware can be used, enhanced, and presented as examples of learning objects in actual teaching situations.

The implications and recommendations arising from the findings obtained in this research project will provide teacher educators with some initial insights when using similar media based products in teacher education.
\end{abstract}

\section{Introduction}

\section{Education reform in Hong Kong}

The Curriculum Development Council (CDC) is a free-standing advisory body appointed by the Chief Executive of the Hong Kong Special Administrative Region (SAR) to provide advice to the Government on curriculum development. In July 2001, the CDC published a curriculum reform report on Learning to Learn - The Way Forward in Curriculum Development, outlining the general direction for curriculum development in Hong Kong for the following ten years. The document specified nine generic skills in teaching and learning, as being necessary to fulfil its vision of enabling students to attain all round development and lifelong learning. These generic skills are considered to be fundamental to helping Hong Kong school students learn better. They are to be developed through learning and teaching in the contexts of different subjects and are transferable to different learning situations. The generic skills include problem solving and the Learning to Learn document has encouraged educators in Hong Kong to consider the use of problem based learning (PBL) in various settings. This is a considerable departure from more traditional local educational practices. 
These developments have been accompanied by increasing interest in the use of information and communication technology to enhance student learning. This paper describes an investigation of the impact of video based stimulus material (sometimes referred to as "triggers") on student attitudes to problem based learning. The investigation that it documents sought to discover whether the use of such material would trigger more effective episodes of learning through student teacher engagement in realistic simulations of actual school experiences.

\section{Problem based learning versus traditional learning}

Problem based learning (PBL) has been said to enjoy many advantages over more traditional ways of learning (Barrows, 1986; Boud \& Feletti, 1997; Coles, 1985; Cunningham \& Cordeiro, 2006; Evensen \& Hmelo, 2000; Harwell \& McCampbell, 2002; Neame, 1982; Savin-Baden, 2000; Uden \& Beaumont, 2006). Staff and students involved in the process seem to find it more enjoyable and stimulating (Olson, 1987) than more traditional approaches. To facilitate the learning process, the problems provided are always open ended and complex, and are presented in a context which is personally relevant to simulate real world experiences (Harper-Marinick \& Levine, 2002, pp. 6-7). Boud and Feletti (1997) briefly describe PBL as "an approach to structuring the curriculum which involves confronting students with problems from practice which provide a stimulus for learning" (p. 15), however they go on to suggest that, "there is no universally agreed set of practices which can be found to define the PBL approach" (p. 2). Table 1 contrasts problem based and traditional learning.

Table 1: A contrast between problem based and traditional learning

\begin{tabular}{|c|c|c|}
\hline & Problem based learning & Traditional learning \\
\hline \multirow{5}{*}{$\begin{array}{l}\text { Differences } \\
\text { in the } \\
\text { learning } \\
\text { process }\end{array}$} & $\begin{array}{l}\text { The stress is on the prior knowledge of } \\
\text { the learners. }\end{array}$ & $\begin{array}{l}\text { The stress is on the lecturer's } \\
\text { knowledge and presentation skill. }\end{array}$ \\
\hline & $\begin{array}{l}\text { Learning is student centred and tends } \\
\text { to promote deep learning. }\end{array}$ & $\begin{array}{l}\text { Learning is teacher centred and may, } \\
\text { thus, lead to shallow and passive } \\
\text { learning. }\end{array}$ \\
\hline & $\begin{array}{l}\text { Knowledge is obtained through } \\
\text { collaborative teamwork in the problem } \\
\text { solving process. }\end{array}$ & Knowledge is generally text based. \\
\hline & $\begin{array}{l}\text { Knowledge is constructed } \\
\text { independently by the students } \\
\text { themselves using authentic cases as } \\
\text { examples with the teachers acting as } \\
\text { facilitators }\end{array}$ & $\begin{array}{l}\text { Knowledge is generally obtained in the } \\
\text { traditional classroom with the teachers } \\
\text { lecturing to the students. Examples are } \\
\text { given as symbolic reasoning. }\end{array}$ \\
\hline & $\begin{array}{l}\text { Problems serve as a stimulus for } \\
\text { learning and for the development of } \\
\text { problem solving skills in an authentic } \\
\text { way. There is no single right answer. }\end{array}$ & $\begin{array}{l}\text { Lectures serve as the main if not the } \\
\text { only vehicles for learning. Concepts } \\
\text { and information tend to be pre- } \\
\text { digested and presented to the learners } \\
\text { as truths with symbolic reasoning. }\end{array}$ \\
\hline
\end{tabular}

The PBL literature seems to suggest that prior knowledge, student centred learning, collaborative work, independent learning, deep learning and authentic case studies are the key elements in enabling the students to achieve in depth and lifelong learning habits. Means (1994) notes that using technology in a constructivist manner will further expand the students' knowledge base and create more global learners. If this is truly the case, the development of educational projects to apply ICT within 
appropriate learning designs may contribute to achievement of the desired PBL learning outcomes in an innovative way. Consequently, examination of the impact of technology on education is also timely.

\section{Attributes of video technology}

Video based learning has many advantages over paper based approaches in teacher education because it offers a greater degree of authenticity by allowing teachers and student teachers to observe other teachers on video, and listen to student interactions. Media rich educational courseware in the form of video cases comprising the visual elements of posture, proxemics, eye contact, facial expression and uses of gesture may offer a means of engaging the student authentically within a PBL case. It is particularly helpful in the early stages of implementing problem based learning with students. Moreover, the combination of visual clues within an effective and systematic exploitation of well-selected video sequences can help increase students' interest and serve as a stimulus for free discussion in group work (Bouthillier \& Dilanni, 2001). When compared with the equivalent text, a video presentation has been shown to be particularly helpful for medical postgraduates working within a PBL learning format (Balslev, de Grave, Muijtjens \& Scherpbier, 2005). The video mediated experience resulted in an improvement in data exploration, theory building and theory evaluation. This paper explores an application of a similar approach to teacher education.

Video can present authentic data. Historically, students in university programs for teacher education had always thought that their preparation for classroom management seemed appropriate until the first day of real teaching, when they suddenly realised that their hands on application of theory was far from adequate (Matus, 1999). It appears that one of the most difficult areas for student teachers during teaching practice is classroom management. Novice teachers are faced with students eager "to test the boundaries and limits of their new teacher" (Keppell, 2006, p. 227). In such cases, exposing pre-service teachers too early to challenging classroom management scenarios beyond their control may actually dent their confidence and derail the development of positive beliefs and attitudes.

Because of this, McCormack (2001) advocates that pre-service teachers need a chance to practise the theory prior to their entering the real situation, although this is one of the most difficult areas to treat authentically through traditional methods. McCormack points out that the coursework in many teacher education programs lacks the practical training aspect which pre-service teachers need in real life classroom management, and that the disciplines which are acquired as theories do not seem to be supported by practice. Clement $(1999,2000,2002)$ supports the assertion that student teachers learn better by initially practising and applying the theories they have acquired in a safe environment without being seen to be making mistakes or causing serious problems in a real classroom. Teaching through simulations, therefore, appears to be ideal for pre-service teacher education.

\section{Development of video rich educational courseware}

According to Reeves (1989), effective video mediated instruction requires that learning objectives be clearly stated; pre-viewing activities are provided; specific, focused viewing activities are presented; viewing is broken into segmented activities; post- 
viewing discussion occurs; follow up activities are provided; and evaluation is conducted. The PBL video rich courseware that was developed and evaluated in the study described by this paper was based on these seven procedures.

Although Herrington, Oliver and Reeves (2002) have pointed to the fact that, "it is impossible to design truly authentic learning experiences" (p. 60), the teacher educators of the Hong Kong Institute of Education (HKIEd) believe that it is still possible to introduce learning experiences that complement and enhance the professional practice of pre-service teachers. Authentic cases of classroom behaviour across a number of disciplines were therefore re-enacted to encourage pre-service teachers to solve complex and ill-structured problems and to help them develop their ability to reflect on their professional practice. The micro-design of each case drew upon the expertise of a number of subject experts within the Institute.

Direct access to actual classrooms is a continuing problem in teacher education. Video technology allows the possibility of greater realism than written text. Digitally recorded episodes may serve as effective 'triggers' for students' work. 'Trigger' seems a suitable descriptor for a virtual experience that prompts students' reflection, investigation, and discussion. The scripts for the video triggers were written specifically to exploit the scope of video technology for portraying interpersonal interactions. Much effort was expended in an attempt to create five provocative cases with which the viewers would be expected to engage (Keppell, 2006).

\section{Methodology}

\section{Case study research strategy}

This investigation into the effectiveness of a newly developed educational product meets the three key criteria of being a "critical" case, a "unique" case and a "revelatory" case (Patton, 2002; Yin, 1989) and so a single case study research strategy was chosen for this study. The theoretical foundation rested on the constructivist theory upon which the PBL concept was based, the case fulfilled the criteria of being unique because the research questions were focused on the application of video rich PBL courseware in the sole specialist teacher education University in Hong Kong and the specific situation of the HKIEd made this case study unique. Finally, it provided insights into the phenomenon of applying technology to enhance the PBL process, and as such it fulfilled the revelatory criteria. To achieve the proposed objectives, both quantitative and qualitative methods were used in the exploratory design of the study, in the process of investigation and in the description of the findings.

Five simulations of common school experiences were recorded. These episodes were designed to stimulate discussion and prompt the initiation of the recursive cycles that characterise problem based learning. Their titles and content areas are set out on Table 2.

The key question of this investigation is "how do education students respond to particular media rich cases for problem based learning?" Throughout the research process, the research objectives are focused upon the specific area of the users' attitudes to the PBL video recordings, specifically on the experience of the student teachers when using multimedia technology and PBL pedagogy; their perceived difficulties in the process; and the possibility of introducing video rich triggers which 
can be adjusted to better suit their needs and encourage wider usage of problem based learning on the HKIEd campus. Probing questions were then used to clarify the experiences and expectations of different groups when using multimedia or adopting problem-based learning; identify the difficulties perceived by different user groups with regard to the newly developed media triggered, problem based learning; and suggest how these learning objects could be better suit to the needs of their potential users.

\section{Data sources}

Ten student groups of five subjects were selected in order to explore diversity, rather than to establish any kind of "representativeness". For the same reason, pre-existing groups of final year students of the same disciplines were chosen because they already knew each other through learning or socialising together throughout their courses of study. The media rich cases were tailor made for prospective teachers of Early Childhood Education, Information Technology, Business Studies, Physical Education, and Inclusive Education, and so final year students who had their major or minor subjects falling into these disciplines were invited to participate in the focus group interviews. Groups of participants were randomly selected from a full list of final year students from the Institute. Since there were five video cases, a total of 10 student groups, involving two groups from each of the subjects, were interviewed.

Final-year students in groups of seven to nine members were invited to attend face to face interviews on the campus immediately after their classes. Preceding the group discussion, an electronic student survey was conducted to gather pre-service teacher views on the benefits of the video recordings, their previous PBL experience and future prospects for applying problem based learning.

Table 2: Background of student focus group participants

\begin{tabular}{|c|c|c|c|c|}
\hline \multirow{2}{*}{$\begin{array}{l}\text { Case } \\
\text { no. }\end{array}$} & \multirow{2}{*}{ Title } & \multirow{2}{*}{ Focus } & \multicolumn{2}{|l|}{ Student interviewees } \\
\hline & & & Speciality/sources & No. \\
\hline 1 & $\begin{array}{l}\text { What's Wrong With } \\
\text { My Baby Boy? }\end{array}$ & $\begin{array}{l}\text { Early childhood } \\
\text { education }\end{array}$ & Early childhood education & 16 \\
\hline 2 & Quantum Leap & $\begin{array}{l}\text { Exercise physiology - } \\
\text { physical education }\end{array}$ & Physical education & 17 \\
\hline 3 & $\begin{array}{l}\text { Why Can't I Save This } \\
\text { File? }\end{array}$ & Digital video production & Information technology & $19^{*}$ \\
\hline 4 & $\begin{array}{l}\text { Just One More Minor } \\
\text { Change... }\end{array}$ & $\begin{array}{l}\text { Project management in } \\
\text { educational technology }\end{array}$ & $\begin{array}{l}\text { Business studies } \\
\text { Home economics }\end{array}$ & 17 \\
\hline 5 & $\begin{array}{l}\text { Do You Want to Play } \\
\text { As Well...? }\end{array}$ & $\begin{array}{l}\text { Inclusive physical } \\
\text { education }\end{array}$ & Inclusive education & 19 \\
\hline \multicolumn{3}{|c|}{${ }^{*}$ one returned questionnaire was invalid } & Total & 87 \\
\hline
\end{tabular}

A majority of the student respondents were female (75\%). The student informants had the following characteristics in common:

i. pre-service teachers in their final year of full time studies;

ii. Hong Kong born Chinese with education received locally;

iii. ranging from 23 to 26 years of age;

iv. having their own computers at home;

v. possessing basic IT skills and having fulfilled the Hong Kong Government's requirement of basic IT Competency level for graduation 


\section{The focus group research process}

The main purpose of using focus groups in this study was to draw upon respondents' attitudes, feelings, beliefs, experiences and reactions in a way which would not be feasible using other methods (Gibbs, 1997). This is because focus groups help elicit a multiplicity of views and emotional processes within a group context, especially where the everyday use of language and the culture of that group is of interest (Morgan \& Kreuger, 1993). This view is echoed by Greenbaum (1998), who advocates that focus group research is particularly useful for new product development studies, attitude studies and idea generation. The group is "focused" in the sense that it can be made to involve some kind of collective activity such as examining a single health education message, debating a particular set of questions or viewing a video related to a particular discipline as in this case. Working with such a group enables one to obtain an insider's view of the social contexts within which ideas were formed and decisions made.

The framework of the focus group study developed by Carson and colleagues (2001) was adopted with modifications (see Table 3).

Table 3: Field procedures for student focus group interviews

\begin{tabular}{|c|c|c|}
\hline Action & Focus & Tasks \\
\hline 1 & Defining the problem. & $\begin{array}{l}\text { Based on the research questions shown in Item one, } 3 \text { key } \\
\text { questions were focused on during the discussion. }\end{array}$ \\
\hline 2 & $\begin{array}{l}\text { Determining the number } \\
\text { of groups. }\end{array}$ & $\begin{array}{l}\text { Ten groups of students were invited to participate with } 7-8 \\
\text { students of the same discipline in each group. Since there } \\
\text { were } 5 \text { video cases, a total of } 10 \text { student groups ( } 2 \text { groups in } \\
\text { each subject) were interviewed. }\end{array}$ \\
\hline 3 & $\begin{array}{l}\text { Number of participants in } \\
\text { each group. }\end{array}$ & $\begin{array}{l}\text { In this research, participants were final year student teachers. } \\
\text { They were from the same education background and shared } \\
\text { a similar experience. Therefore, a group size of } 7-8 \\
\text { participants was adopted. }\end{array}$ \\
\hline 4 & Length of each session. & $\begin{array}{l}\text { Durations of } 0.5 \text { hour for discussions were typical (Carson et } \\
\text { al., 2001). }\end{array}$ \\
\hline 5 & Selection of site. & $\begin{array}{l}\text { On the campus following the same strategy as for the } \\
\text { personal interviews with teacher educators. }\end{array}$ \\
\hline 6 & Timing. & $\begin{array}{l}\text { Interviews were taken immediately after completing the } \\
\text { questionnaire. }\end{array}$ \\
\hline 7 & $\begin{array}{l}\text { Recruitment of the } \\
\text { participants. }\end{array}$ & $\begin{array}{l}\text { Voluntary participants were invited through their subject } \\
\text { teachers at the end of the class. }\end{array}$ \\
\hline 8 & Selection of the moderator. & $\begin{array}{l}\text { According to Carson et al. (2001), the moderator should be } \\
\text { the one who is familiar with the topic of discussion. } \\
\text { Therefore, the researcher of this project was the moderator. }\end{array}$ \\
\hline 9 & Conducting the discussion. & Notes were taken during all focus group discussions. \\
\hline 10 & $\begin{array}{l}\text { Analysis of the } \\
\text { information. }\end{array}$ & $\begin{array}{l}\text { Notes were coded to identify themes which emerged, and } \\
\text { which had been prompted by the interview protocol. }\end{array}$ \\
\hline
\end{tabular}

Source: Adapted from Carson, Glinow \& Gronhaug (2001)

The focus group interview started by inviting the students to complete a bilingual electronic questionnaire. The questions were adapted from the questionnaires approved by the Institute's Teaching and Learning Process Quality Review (TLPQR) for course evaluation at the end of each semester. It was a requirement of the University Grants Committee (UGC) of the Hong Kong Government to carry out a program of TLPQRs in all UGC funded tertiary institutions. Reviews were carried out 
as part of the on going activities of UGC designed to assure quality and value for money. There were a total of 20 questions.

The first 12 questions asked about the respondents' views on the perceivable benefits of the PBL videos, such as: authentic learning, independent learning, deep learning enhancement, collaborative learning, student centred learning, and inclusion and expansion of prior knowledge. The English text of these questions appears in Table 4.

The next three questions (Qs. 13-15) looked into the students' PBL experience and perspectives. Another three (Qs. 16-18) were open ended questions designed to seek the students' general views on the videos. The last two questions (Qs. 19-20) were intended to obtain the respondents' major and minor courses of study. The length of the whole questionnaire was considered to be appropriate as the questions concerned the video related to their discipline which they had devoted considerable time and effort in and, thus, gave them the incentive to respond and provide a useful feedback. In an attempt to obtain a better response, a covering sheet providing an overview of PBL pedagogy was enclosed (Zikmund, 1991).

Immediately following the completion of the electronic questionnaires, students were invited to join a focus group discussion to express their further views on the three open ended questions regarding the learning process (Qs. 16-18).

\section{Findings}

\section{Results of student survey}

Before presenting the results of the student focus-group survey, let us first look into the respondents' background and their basic attitudes to problem based learning (Questions 13-15 on the questionnaire). Almost 70\% of student respondents indicated that they had some experience of learning through PBL. However, only $45 \%$ indicated that they had been taught how to use it. PBL was only introduced officially to the curriculum at HKIEd during the recent years, as an optional subject under an elective "Effective Classroom" module, so this is not surprising. The majority of the teacher educators in the Institute were either using problem oriented or problem solving approaches, which probably also contributed to this lack of direct student instruction in this innovative pedagogy. Just over $70 \%$ of the student respondents who completed the survey suggested that they intended to use PBL in their own teaching.

Table 4 reflects 87 student responses to the first twelve questions of the electronic questionnaire. The questions used a Likert scale of Strongly Disagree (coded as '5') to Strongly Agree (coded as '1'). This coding means that a mean score below 3 represents sample agreement with the statement.

About half of the student respondents suggested that the video triggers were realistic, helpful, encouraged them to make good use of other resources, deepened their understanding of subject matter and helped them to integrate learning. More than two thirds suggested that the media rich approach to PBL helped them apply their own knowledge, stimulating them to think and attempt problem solutions. Similarly high proportions expressed positive views of student centred learning and the contribution of media triggered PBL to building team membership and communication skills. 
Table 4: Student questionnaire responses

\begin{tabular}{|c|c|c|c|c|c|c|c|c|c|}
\hline $\begin{array}{l}\text { Initial } \\
\text { theme }\end{array}$ & No. & Question & $\begin{array}{c}\mathrm{SD} \\
\%\end{array}$ & $\begin{array}{l}\mathrm{D} \\
\%\end{array}$ & $\begin{array}{l}\mathrm{N} \\
\%\end{array}$ & $\begin{array}{l}\mathrm{A} \\
\%\end{array}$ & $\begin{array}{c}\mathrm{SA} \\
\%\end{array}$ & Mean & SD \\
\hline \multirow{9}{*}{$\begin{array}{l}\text { Benefits } \\
\text { of } \\
\text { problem } \\
\text { based } \\
\text { learning }\end{array}$} & 1 & $\begin{array}{l}\text { The video presented similar } \\
\text { situations in the real world }\end{array}$ & 3 & 13 & 34 & 48 & 1 & 2.69 & .84 \\
\hline & 2 & $\begin{array}{l}\text { The video helped me to develop my } \\
\text { knowledge and skills for the teaching } \\
\text { profession }\end{array}$ & 5 & 13 & 33 & 46 & 3 & 2.69 & .91 \\
\hline & 3 & $\begin{array}{l}\text { The question posted in the video } \\
\text { encouraged me to learn by making } \\
\text { good use of the resources inside and } \\
\text { outside the institute }\end{array}$ & 3 & 11 & 40 & 40 & 5 & 2.69 & .87 \\
\hline & 4 & $\begin{array}{l}\text { After watching the video, it helped } \\
\text { me to apply my own knowledge to } \\
\text { find a solution }\end{array}$ & 5 & 6 & 23 & 61 & 6 & 2.43 & .87 \\
\hline & 5 & $\begin{array}{l}\text { The learning activity deepened my } \\
\text { understanding of the subject matter }\end{array}$ & 1 & 10 & 33 & 51 & 5 & 2.53 & .79 \\
\hline & 6 & $\begin{array}{l}\text { The learning activity stimulated me } \\
\text { to think }\end{array}$ & 1 & 15 & 20 & 57 & 7 & 2.46 & .87 \\
\hline & 7 & $\begin{array}{l}\text { The learning activity helped me } \\
\text { integrate learning from different parts } \\
\text { of the subject }\end{array}$ & 1 & 18 & 33 & 43 & 5 & 2.69 & .87 \\
\hline & 8 & $\begin{array}{l}\text { After watching the video, it trigger-ed } \\
\text { me to think about the solution and try } \\
\text { to solve the situation }\end{array}$ & 2 & 5 & 23 & 60 & 10 & 2.29 & .81 \\
\hline & 9 & $\begin{array}{l}\text { The learning activity gave me the } \\
\text { chance to build up my own style and } \\
\text { pace of learning }\end{array}$ & 0 & 18 & 40 & 40 & 1 & 2.76 & .76 \\
\hline \multirow{3}{*}{$\begin{array}{l}\text { Group } \\
\text { discuss- } \\
\text { ion }\end{array}$} & 10 & $\begin{array}{l}\text { I like student centered classes with } \\
\text { lots of discussions }\end{array}$ & 2 & 10 & 18 & 57 & 11 & 2.34 & .90 \\
\hline & 11 & $\begin{array}{l}\text { Group discussion made me an } \\
\text { effective member of a team }\end{array}$ & 1 & 2 & 26 & 63 & 7 & 2.28 & .68 \\
\hline & 12 & $\begin{array}{l}\text { Group discussions enhanced my } \\
\text { communication skills }\end{array}$ & 1 & 2 & 13 & 67 & 17 & 2.03 & .71 \\
\hline
\end{tabular}

\section{Analysis of the student survey}

\section{Two-tailed significance level}

Independent sample tests were conducted for Questions 1-12 to examine the differences of means between those respondents who reported that they "would try to use PBL when teaching in the future" and those who "would not try to use PBL when teaching in the future" (Question 15 on the electronic survey). There was a statistically significant difference on eight of the twelve questions included on Table 4 (Qs. 2, 3, 4, $6,7,8,9,10)$. Teacher trainees who reported that they "would try to use PBL when teaching in the future" had higher levels of agreement $(p<0.05)$ with all of these questions than those teacher trainees who reported that they "would not try to use PBL when teaching in the future". There is a statistically significant association of positive response with positive intent and this may well have practical implications.

The findings point out the importance of providing training to the student teachers to help them understand the potential benefits of the PBL pedagogy. Once they realise the achievable benefits, they will be more willing to apply the PBL teaching approach in their practical work. Ward (2001) echoes the belief that "the central figure 
responsible for producing change is the teacher" (p. 94). As Windschitl (2002) asserts, "one of the most powerful determinants of whether constructivist approaches flourish or flounder in classrooms is the degree to which individual teachers understand the concept of constructivism" (p. 138). Both Ward and Windschitl advocate that teachers must learn about the underlying theory in order to know what types of activities are appropriate for specified learning goals. According to their studies, in the absence of some other teaching models, teachers tend to teach in the way which they were taught themselves, and most teachers were taught by the traditional and didactic methods.

Both Ward and Windschitl lament the fact that even pre-service student teachers at colleges of education are still being taught the theories and concept of constructivism through the conventional teacher centred method (Hausfather, 2001; Smerdon, Burkam, \& Lee, 1999). Therefore, changes in teaching methods towards constructivism and student centred learning must be introduced at the very beginning of the courses given to pre-service teachers. In addition, the student teachers need to be given special training in some crucial skills such as developing proficiency in creating PBL projects, developing expertise in using video tools as a vehicle for instruction, and recognising and solving issues arising in the progress of a PBL project. Such experiences allow prospective teachers to engage with real world problems that require them to find, evaluate, and use appropriate learning resources, just as they would expect their students to do. To allow students experience as PBL learners they need to design their own PBL units, and practise the coaching skills that they will then try out in their own teaching situations.

These research findings indicate that the movement of the teaching profession toward PBL has to begin at the very start of the teacher education and preparation program.

\section{Factor analysis}

A factor analysis, using a Varimax rotation with Kaiser normalisation, of Questions 1 to 15 resolves into four components which accounted for $100 \%$ of the total variance. These factors were benefits (1), pedagogy (2), group work (3) and PBL experience (4). Applying factor analysis in this study helped to identify clusters of learning results and to identify multiple questions that might measure the same factor. As a result, the analysis provided justification for including fewer questions in certain areas, for example, the potential PBL learning outcomes triggered by the videos. Questions clustered under a particular factor correlate highly with other members of the group but not with items in other factors.

Questions 1 to 9 have a bearing on Factor 1 which looks to the perceived benefits of PBL. Questions 11 and 12 "Group discussions made me an effective member of a team" and "Group discussions enhanced my communication skills" have an important bearing on Factor 3 which reflects the respondents' views of group discussions. Similarly, Questions 13 to 14 "I have had the experience of learning through problem based learning before" and "I have been taught how to use problem based learning during my teacher education training" have a bearing on Factor 4 which seems to reflect the respondents' experience of problem based learning and their perspective on future use of it.

Some components did not have a bearing on the factors with which they might be expected to connect. Question 10 "I like student centred classes with lots of discussion" did not correlate with Questions 11 and 12. This result may imply that the 
approach of group discussion was viewed differently in Asian countries than in the Western world. The difference may have roots in the traditional Chinese culture in the local society. In general, the Chinese students appear to be passive in class and seldom speak up. They avoid challenging other people's ideas as their culture emphasises harmony in groups. These results suggest that special training, such as group dynamics or collaborative skills, is required for students to achieve meaningful and successful group work.

It is, however, interesting to note that Questions 2, 3, 10, and 15 have a bearing on Factor 2. The questions of "The video helped me to develop my knowledge and skills for the teaching profession", "The question which posted in the video encouraged me to learn by making good use of the resources inside and outside the Institute", "I like student centred classes with lots of discussions" and "I shall try to use problem based learning in my future teaching work" were, thus, not considered to be separated from Factors 2 and 4 . The results may suggest that the student respondents are interested in exploring innovative methods for teaching and are eager to try out these new approaches in their future work.

\section{Findings of focus group interviews}

The main points were summarised by the researcher and then presented again to the group to seek their general agreement, in order to determine how useful they had perceived the PBL videos to be and how much use they would make of them in the future. The focus group interviews were intended to illuminate tendencies visible in the quantitative results. Table 4 provides typical responses that are expanded in the discussion below.

The following concerns were mentioned by the students at all of the ten focus group interviews:

\section{Group size}

The student teachers mentioned their concern about the large class size in Hong Kong schools. Many PBL experts had already argued that 'proper' PBL could only exist in a recommended group of no more than seven, with a trained tutor for every group. With nine or more groups, having every group work and report on their own problems and solutions could make the participants feel redundant and become bored.

It will be particularly difficult for me as a novice teacher... because I'll need to manage the large class size and take care of classroom management at the same time (Student A)

\section{Group dynamics}

Although small group collaboration was encouraged for promoting PBL learning, student teachers expressed their concerns about "free riders" (Salomon \& Globerson, 1989).

...we were brought up in a way of competing with each other to get higher marks (Student B)

The positive attitude toward the educational value of group work might be hindered by the participants' frustration with one or more group members who had not contributed sufficiently in their previous group work project. 
Table 4: Open ended Questions 16-18

\begin{tabular}{|c|c|}
\hline Questions 16-18 & A brief summary of the direct quotes from the respondents \\
\hline \multirow{5}{*}{$\begin{array}{l}\text { 16. What aspects of } \\
\text { the learning } \\
\text { process did you } \\
\text { find most } \\
\text { impressive and } \\
\text { why? }\end{array}$} & $\begin{array}{l}\text { Applicable to real life; understanding the practical areas particularly where } \\
\text { the cases given seemed to be relevant and helped me to think in depth. }\end{array}$ \\
\hline & $\begin{array}{l}\text { Realistic cases; seeing examples of how to work out solutions and how to } \\
\text { deal with the problems which might happen daily. }\end{array}$ \\
\hline & $\begin{array}{l}\text { Strong teamwork; seeing everyone involved in the discussion no matter } \\
\text { how difficult the questions were (no consensus). }\end{array}$ \\
\hline & $\begin{array}{l}\text { Creativity of the videos; presenting examples of how we could apply the } \\
\text { solutions on our own in a creative way. }\end{array}$ \\
\hline & $\begin{array}{l}\text { Interesting way of learning; changing from the conventional way of } \\
\text { receiving lectures from the tutor to an interactive way of self learning. }\end{array}$ \\
\hline \multirow{5}{*}{$\begin{array}{l}\text { 17. What aspects of } \\
\text { the learning } \\
\text { process could have } \\
\text { been changed to } \\
\text { make it more } \\
\text { useful to my } \\
\text { teaching? }\end{array}$} & Process: Demonstrating more about the PBL process. \\
\hline & $\begin{array}{l}\text { Problem development: Introducing what is to be discussed for the } \\
\text { problem. Not enough time to make full use of the PBL process. }\end{array}$ \\
\hline & $\begin{array}{l}\text { Guidelines: Suggesting the problems of the presented case and guidelines } \\
\text { for discussion }\end{array}$ \\
\hline & Assessment: Proposing ways of assessing the learning outcomes. \\
\hline & $\begin{array}{l}\text { Authenticity: Providing more cases on other authentic problems related to } \\
\text { novice teachers. }\end{array}$ \\
\hline \multirow{7}{*}{$\begin{array}{l}\text { 18. Any other } \\
\text { comments / } \\
\text { suggestions? }\end{array}$} & Group size; facing a large class size in most of the local schools. \\
\hline & $\begin{array}{l}\text { Group dynamics; getting everyone involved in the collaborative } \\
\text { groupwork is difficult. }\end{array}$ \\
\hline & $\begin{array}{l}\text { Insufficient training: Developing the media courseware by the teachers } \\
\text { themselves in addition to the daily heavy workload. }\end{array}$ \\
\hline & $\begin{array}{l}\text { Insufficient resources: lacking sufficient technical support/ equipment in } \\
\text { their attached schools. }\end{array}$ \\
\hline & $\begin{array}{l}\text { Question development: Frustrating when developing their questions and } \\
\text { answers, and being not able to obtain help from tutor. }\end{array}$ \\
\hline & PBL training: Introducing more about the PBL pedagogy is required. \\
\hline & $\begin{array}{l}\text { Cultural issues: Changing the learning style of local students who get used } \\
\text { to being given the answers. }\end{array}$ \\
\hline
\end{tabular}

Time constraints

The large amount of time required to be invested in PBL is another major concern, which includes the time required for creating a problem, preparing its supporting materials, as well as facilitating communication between the facilitator and the student learners is tremendous. As Barrows and Tamblyn (1980) have stated, "many critics of PBL see the procedure as an inefficient way to learn because when students are confronted with an unfamiliar problem they require inordinate amounts of time to understand the terminology and the dynamics associated with the problem" (p. 14).

I could foresee the difficulties in using PBL in my future teaching work. The resources required for PBL can be very demanding. I will have to change much of my teaching style but my students may find it difficult to cope with the new way of learning. (Student C) 
Assessment of learning outcomes

The student teachers were concerned about how to assess the learning outcomes.

Chinese cultures place much value on diligence, working hard, and making an effort to memorising information. Same as my [parents], most Chinese parents strongly believe that one's efforts determine one's grades. Success at school by obtaining good grades is the only objective of schooling for their children. (Student D)

This echoes the views of Barrows and Tamblyn (1980, p. 14) who stated that "this method seems to stress problem solving skills and not the acquisition of knowledge or facts... and this method of learning does not facilitate the student's ability to pass certifying examinations" (p. 14). They suggested that PBL requires assessments which measure the students' applied learning skills such as presentations and action plans, as students showed only slight improvement when they were tested with factual subject oriented questions.

\section{Analysis of focus group interviews}

The focus group interviews were taped and then transcribed. The transcriptions were analysed through the use of NVivo. The software generated nodes which were similar to the tendencies emerging from analysis of the questionnaire data.

The opinions obtained from the student focus group interviews appear to confirm that these video rich PBL learning objects are well received by the student teachers, who could already appreciate the potential benefits of this approach for professional teacher training. The findings suggest that training is important for student teachers in order to help them understand the potential benefits of PBL pedagogy. However, knowing the benefits of an approach may not necessarily mean that the teachers will adopt it in the classroom.

These PBL video recordings were well received by the pre-service teachers. These learning objects achieved their original purpose of arousing the interest of people who were not familiar with PBL. Most of the research participants were impressed by the authenticity of the cases and the technological complexity of the videos, and agreed that the desired learning outcomes would be likely to be achieved through media rich PBL learning objects. They suggested that this was because of the following attributes found in the video recordings:

1. The learning objects provide authentic scenarios whereby the student teachers are expected to acquire skills or knowledge to solve the problem;

2. The learning process covers the six modes of learning; in particular, learning by doing and learning by teaching;

3. Student teachers are required to use their prior knowledge to solve the problems raised;

4. Student teachers are required to work collaboratively in groups;

5. Emphasis is placed on the creativity of identifying the problem and producing a workable solution which has sociological relevance, thereby making appropriate use of their prior knowledge and developing their practical problem solving skills;

6. There is an innovative change from conventional lectures by tutors to a more interactive approach to self and independent learning. 


\section{Conclusion}

The results of this investigation suggested that problem based learning supported by media rich educational courseware can offer a means of providing authentic scenarios for assisting pre-service teachers to obtain the knowledge they need before teaching practice, because those authentic cases might help student teachers to bridge the gap between theory and practice.

The major objective of PBL is to promote independent learning and ultimately lifelong learning. As revealed from the case of this teacher training institution, PBL provides the student teachers with a new and exciting way better prepare for their professional careers. One of the strong arguments used in support of PBL in education is that it provides a learning experience which is much more enjoyable than sitting through long hours of lectures in a conventional curriculum. The argument that has been put forward is coupled with a desire to instil in students a joy of learning that will nurture them to become lifelong learners (Albanese \& Mitchell, 1993, p. 63).

However, the results of this investigation indicate that previous successful experience with PBL can exert a significant influence on its adoption by Chinese students. Almost all of the participants involved in this study believe that certain skills were prerequisites to success: the skills they specified included managing the PBL process, case analysis and problem identification, solution development and assessment of learning results, as well as techniques in handling the large class size and the dynamics of more independent groups of school pupils. The consensus amongst the student participants in this investigation seems to suggest that there are a number of problems that need to be addressed if the true benefits of switching to PBL in the local education sector are to be gained. It is hoped that the insights derived from the data will form a valuable baseline for conducting a longitudinal study to determine the extent to which this multimedia educational courseware can affect the processes of learning, as well as to identify the achievable learning outcomes when evaluating the usefulness of video rich triggers in a teacher education context.

\section{References}

Albanese, M. A., \& Mitchell, S. (1993). Problem-based learning: A review of literature on its outcomes and implementation issues. Academic Medicine, 68(1), 52-81.

Balslev, T., de Grave, W. S., Muijtjens, A. M. \& Scherpbier, A. J. (2005). Comparison of text and video cases in a postgraduate problem-based learning format. Medical Education, 39, 10861092.

Barrows, H. S. (1986). A taxonomy of problem-based learning methods. Medical Education, 20, 481-486.

Barrows, H. S. \& Tamblyn, R. M. (1980). Problem-based learning: An approach to medical education. New York: Springer.

Boud, D. \& Feletti, G. I. (1997). The challenge of problem-based learning. London: Kogan Page.

Bouthillier, L. \& Dilanni, J. (2001). Video in education. Paper presented at the RealNetworks Conference 2001, Developing an E-Learning Solutions Strategy, Seattle, WA.

Carson, D., Gilmore, A. \& Gronhaug, K. (2001). Qualitative marketing research. London: Sage Publications. 
Clement, M. C. (1999). Student teachers' perceptions of their preparedness for classroom management. Paper presented at the meeting of the Georgia Association of Teacher Educators, Savannah, GA.

Clement, M. C. (2000). Building the best faculty: Strategies for hiring and supporting new teachers. Lanham, MD: Scarecrow Press/Technomic Books.

Clement, M. C. (2002). What cooperating teachers are teaching student teachers about classroom management. The Teacher Educator, 38(1), 47-62.

Coles, C. R. (1985). Differences between conventional and problem-based curricula in their students' approaches to studying. Medical Education, 19, 308-309.

Cunningham, W. G. \& Cordeiro, P. A. (2006). Educational leadership: A problem based approach (3rd ed.). Boston: Pearson Education.

Evensen, D. H. \& Hmelo, C. E. (Eds.) (2000). Problem-based learning: A research perspective on learning interactions. Mahwah, NJ: L. Erlbaum Associates.

Gibbs, A. (1997). Focus groups. Social Research Update, 19. [viewed 17 July 2006, verified 14 May 2008] http: / / sru.soc.surrey.ac.uk/SRU19.html

Greenbaum, T. L. (1998). The handbook for focus group research (2nd ed.). Thousand Oaks, CA: Sage Publications.

Harper-Marinick, M. \& Levine, A. (2002). Thriving in academe: Understanding problem-based learning. National Higher Education Advocate Online, December. [viewed 10 July 2006, verified 14 May 2008] http: / / www2.nea.org/he/advo02/advo1202/thriving.html

Harwell, R. \& McCampbell, B. (2002). Using the Internet to facilitate problem-based learning. Principal Leadership, 2(6), 63-65.

Hausfather, S. (2001). Where's the content? The role of content in constructivist teacher education. Educational Horizons, Fall, 15-19. [verified 14 May 2008] http:/ / pilambda.org/horizons/v80-1/ hausfather.pdf

Herrington, J., Oliver, R. \& Reeves, T. C. (2002). Patterns of engagement in authentic online learning environments. In Winds of change in the sea of learning. Proceedings ASCILITE 2002, Auckland, New Zealand.

http: / / www.ascilite.org.au/conferences/auckland02/ proceedings/ papers / 085.pdf

Keppell, M. (2006). Authentic cases and media triggers for supporting problem-based learning in teacher education. In A. Herrington \& J. Herrington (Eds.), Authentic learning environments in higher education (pp. 224-242) Hershey, PA: Information Science Publishing.

Matus, D. E. (1999). An innovative strategy supports student teachers in urban secondary schools. The Clearing House, 73(5), 37-41.

McCormack, A. C. (2001). Investigating the impact of an internship on the classroom management beliefs of preservice teachers. The Professional Educator, 23(2), 11-22.

Means, B. (1994). Introduction: Using technology to advance educational goals. In B. Means (Ed.), Technology and education reform: The reality behind the promise (pp. 1-22). San Francisco, CA: Jossey-Bass.

Morgan, D. L., \& Kreuger, R. A. (1993). When to use focus groups and why. In D. L. Morgan (Ed.), Successful focus groups. London: Sage Publications.

Neame, R. L. B. (1982). Academic roles and satisfaction in a problem-based medical curriculum. Studies in Higher Education, 7(2), 141-151. 
Olson, J. O. (1987). The McMaster philosophy: A student's perspective on implementation. Medical Education, 21, 293-296.

Patton, M. Q. (2002). Qualitative evaluation and research methods (3rd ed.). Thousand Oaks, CA: Sage Publications.

Reeves, E. (1989). 7-step lesson plan for using instructional TV in the classroom. [viewed 23 July 2006, verified 14 May 2008]

http:/ / www.unctv.org/education/tvforlearning/usingtv/educators_usingtv.html

Salomon, G. \& Globerson, T. (1989). When teams do not function the way they are supposed to. International Journal of Educational Research, 13(1), 89-98.

Savin-Baden, M. (2000). Problem-based learning in higher education: Untold stories. Buckingham, United Kingdom: Society for Research into Higher Education \& Open University Press.

Smerdon, B., Burkam, D. \& Lee, V. (1999). Access to constructivist and didactic teaching: Who gets it? Where is it practiced? Teachers College Record, 101(1), 5-34.

Student Affairs Office (2006). 2006-2007 A Profile of New Full-time Students. Hong Kong: The Hong Kong Institute of Education.

Uden, L. \& Beaumont, C. (2006). Technology and problem-based learning. Hershey, PA: Information Science Publishing.

Ward, C. (2001). Under construction: On becoming a constructivist in view of the standards. Mathematics Teacher, 94(2), 94-96.

Windschitl, M. (2002). Framing constructivism in practice as the negotiation of dilemmas: An analysis of the conceptual, pedagogical, cultural, and political challenges facing teachers. Review of Educational Research, 72(2), 131-175.

Yin, R. (1989). Case study research: Design and methods (Rev. ed.). Newbury Park, CA: Sage Publications.

Zikmund, W. G. (1991). Exploring marketing research (4th ed.). Chicago: Dryden Press.

Dr Angela Kit Fong Ma, Assistant Education Technology Officer, Centre for Learning, Teaching and Technology, The Hong Kong Institute of Education. 10 Lo Ping Road, Taipo, Hong Kong. Email: kfma@ied.edu.hk

Dr John Mitchell O'Toole, Convenor of Secondary, Science Education Programmes, and Senior Lecturer, School of Education, Faculty of Education and Arts, The University of Newcastle. University Drive, Callaghan NSW 2308, Australia. Email: mitch.otoole@newcastle.edu.au

Professor Michael James Keppell, Director, The Flexible Learning Institute, Charles Sturt University, Murray School of Education. Elizabeth Mitchell Drive, Albury NSW 2640, Australia. Email: mkeppell@csu.edu.au 